\section{Tomato Transplant Age: A Review}

\author{
Charles S. Vavrina and Michael D. Orzolek ${ }^{2}$
}

Additional index words. Lycopersicon esculentum, containerized tram-plants, vegetable transplants, bare-root transplants, trimming, topping, seeding depth, plant population, plugs

Summary. As early as 1929, university scientists began the quest to determine the ideal age at which to transplant tomatoes (Lycopersicon esculentum Mill.). Investigations have included seedlings of 2 to 15 weeks of age produced in wood, peat, plastic, or Styrofoam containers. Early researchers often omitted descriptions of soil mixes and nutrient regimes, and used a wide variety of container types. Later investigators were inclined to use commercial soilless mixes, well-defined nutrient regimes, and polystyrene trays. Pioneers of transplant age research tended to use plants of 7 weeks and older, whereas work within the past 30 years has concentrated on younger plants. Many researchers drew conclusions after only 1 year of experimentation, while others found that results varied across years. Prior to the 1980s, virtually all studies were initiated and conducted in areas far from the thriving transplant industry established in the southeastern United States. Southerngrown transplants often were not in cluded for comparison, and few studies were implemented using plants grown under commercial conditions. After more than 60 years of transplant age research, it appears that transplants of 2 to 13 weeks can produce comparable yields, depending on the many factors involved in commercial production.

\section{Historical database}

One of the first documented studies on tomato transplant age occurred in 1929 under the guidance of I.C. Hoffman of Ohio State Univ. Cultural aspects of the study were not well-

\footnotetext{
${ }^{{ }^{1}}$ Department of Horticultural Sciences, University of Florida, Southwest Florida Research and Education Center, Immokalee, FL 33934.

${ }^{2}$ Department of Horticulture, The Pennsylvania State University, University Park, PA 16802.

Florida Agricultural Experiment Station Journal Series
} number $R-03125$. defined; however, a greenhouse tomato crop was produced with 5-, 6-, 9-, and 10-week-old transplants. Hoffman (1929) found that older tomato transplants ( 9 and 10 weeks of age) produced earlier yields than younger plants, but the younger plants produced greater total yields (Table 1). Eighteen years later, in Ithaca, N.Y., Ernest Casseres (1947) raised 'Earliana' fresh-market tomato seedlings of 7 , 11 , and 15 weeks in wooden flats. His study superimposed a spacing within the flat and a trimming factor on the age component; therefore, no true control was used. No information was provided on the medium or fertilizer program used to raise the plants. One also must assume the planting technique was a modified bare-root approach, as the plants most likely were "pulled"" from the medium.

The study demonstrated that 7week-old plants produced greater early and total yields compared to 11- and 15-week-old transplants. Casseres suggested that older plants of 11 and 15 weeks were overly hardened. He also observed higher yields when transplants were spaced more widely within the tray and that trimming the foliage produced no significant effect. The following year, a colleague of Casseres, Charles Sayre, reported on a 2-year study at Geneva, N.Y., that used a flatraised, fresh-market variety, John Baer, for canning. Sayre (1948) ran a factorial experiment comparing three transplant ages and four methods of growing plants (standard, trimming, plant populations, deeper seeding depth). Transplant ages of 6,8 , and 10 weeks were used the first year, while 10-, 12-, and 14-week-old transplants were used the second year. Sayre offered no information on transplant culture, field preparation, or plant population. $\mathrm{He}$ did, however, include three study locations to consider environmental variation. Year one of Sayre's study showed 6- or 8-week-old plants produced greater early yields than the 10week-old transplants. In year two, 10week-old transplants produced the greatest early yield. Significant yield effects were evident at all three loca- tions in year one, but at only one location in year two. Total yields were similar across treatments both years, and growing method and date interactions were not significant either year. Sayre also found topping and greater space within the flat could improve early yields, but deeper seeding had no effect on yield.

Thirteen years passed before E.W. Chipman (1961) in Kentville, Nova Scotia, performed a similar study. 'Scotia', a determinate, fresh-market tomato, was seeded and then "pricked off to flats" 7 days later. Chipman also incorporated a trimming component, but included true controls of 7, 8, 9, 10,11 , and 12 weeks of age. No mention of medium, fertilizer program, transplanting techniques, soil parameters, or plant populations was made in Chipman's study.

Interestingly, Chipman found that the earliest tomatoes came from the 8or 9-week-old untrimmed transplants, although he admitted the yields were undersized. Greatest yields from untrimmed transplants, both early and total, were obtained with 7-week-old transplants in most cases. He further asserted that trimming $(17,27,37$, or 47 days from seeding) could increase yields significantly in some years.

Nicklow and Minges (1962) were the first to introduce a study with containerized tomato transplants ('Fireball') in Ithaca, N.Y. They performed three studies with transplants: 6 and 9 (60 days) weeks of age; 4, 6, and 8 weeks of age; and 3, 5, 7, and 9 weeks of age. One experiment used plants a) seeded directly into flats, b) seeded into flats then "spotted" (assumed "pricked" off to wider spacing in another flat), c) seeded directly into 2inch Jiffy ${ }^{\mathrm{TM}}$ pots, and d) seeded directly into 3-inch Jiffy ${ }^{\mathrm{TM}}$ pots. The plants were grown in the greenhouse under $70 / 60 \mathrm{~F}$ day/night temperatures and eventually were transplanted into 10inch pots, staked, pruned, and grown in the greenhouse. Another experiment imposed growing temperature, flat spacing, and nitrogen rate variables on the age groups. No mention of medium, fertilizer program, transplanting techniques, or field parameters was made.

Based on these studies, Nicklow and Minges concluded that transplants of 3 and 5 weeks were "ideal" for more fruit and larger fruit size. They contended that earlier yields produced by 
older plants ( 8 to 9 weeks) were the result of an advanced physiological age (i.e., advanced flower bud development.) Twenty years later, Cooper and Morelock (1983) published their work conducted in Bradley County, Ark. Using 'Traveler '76', a fresh-market tomato, they raised transplants of 5, 7, 9 , and 11 weeks of age in 3-inch peat pots. The 5-, 7-, and 9-week-old transplants all had greater early yields than the 11-week-old transplants, and the 5-week-old transplants had greater total yields than the 11-week-old transplants (P.E. Cooper, personal communication), Individual fruit weight was greater with 5-week-old transplants throughout the study.

Liptay (1987), in Ontario, Canada, conducted transplant age work with 'H-2653' processing tomatoes. He designed a factorial study with four cell sizes $\left(3,5.5,10\right.$, and $\left.35 \mathrm{~cm}^{3}\right)$ and four transplant ages (4, 5, 6, and 7 weeks). Using containerized trays made by Plastomer (Barrie, Ont., Canada) and Blackmore (Belleville, Mich.), he compared the age treatments with bareroot plants shipped from the southeastern United States. Liptay provided no information on plant rearing, but implemented his study at two sites. Early yields were similar across all plant ages when grown in $35-\mathrm{cm}^{3}$ cells. As cell size diminished, older transplants (6 and 7 weeks) tended to exhibit greater early yields. Differences in total yields among the transplant age treatments did not occur.

Weston and Zandstra (1989), working with the $100 \mathrm{~A}\left(18.8-\mathrm{cm}^{3}\right)$ $\operatorname{Todd}^{\mathrm{TM}}$ flat (Speedling Inc., Sun City, Fla.) in Michigan, were the first to provide detailed information on soilless mix, polystyrene trays, greenhouse fertilization, and field fertilization. Using 'Pik-Red fresh-market tomatoes, they established age treatments of $3,4,5$, and 6 weeks. In addition, a $\mathrm{N}$ and $\mathrm{P}$ component was superimposed on the age study.

Their 4- and 5-week-old transplants produced greater early yields than the 3- and 6-week-old transplants. Higher early yields were the result of more fruit per plant-not larger fruit. The 6-week-old transplants produced higher total yields than either the 3- or 4-week-old plants. Early and total yield decreased linearly with decreasing transplant age. Weston and Zandstra concluded that a 4- to 5-week-old transplant fertilized with high $\mathrm{N}$ and moderate $\mathrm{P}$ was ideal for high early and total yields.

Leskovar et al. (1991a) produced the first study grown under a flotation irrigation system. Two studies conducted at separate sites in Florida used 'Sunny', a fresh-market cultivar. They used 3-, 4-, 5-, and 6-week-old plants in the spring and 2-, 3-, 4-, and 5week-old plants in the fall. These researchers used commercially produced containerized transplants (Speedling Inc., Bushnell, Fla.) and offered complete information on cultural techniques used to raise the plants. Commercial planting practices were detailed, and the study plants were grown under both subsurface seepage and drip irrigation in Florida.

These researchers showed that, in spring, when harvests were pooled, early and total yields were similar across transplant ages. However, a quadratic response existed with respect to fruit size-the 5-week-old transplants produced more early large fruit, while the 4-week-old plants produced more total large fruit. The fall study resulted in similar fruit yields for all transplant ages, and no differences in fruit size. They concluded that "the growth advantages of younger transplants... eventually translated into similar or higher yields of large fruit." Therefore, the traditional 5- to 6-week-old southern containerized transplant offered no greater advantage to the grower than a 3- to 4-week-old transplant.

Prompted by the catastrophic freeze of 1989 in Florida, and the often-delayed planting schedules in Pennsylvania, we planned an age study with commercially grown tomato transplants (Redi Plants, Naples, Fla.). Two studies were conducted in Pennsylvania in 1990 and 1991 (Orzolek et al., 1991), and one study in Florida in 1990 (Vavrina, 1991). The Pennsylvania studies included plants of 3, 4, 7, 9, and 11 weeks of age in 1990, and 3, 5, $7,9,11$, and 13 weeks of age in 1991 . The Florida study included plants of 3 , $5,7,9$, and 11 weeks of age.

In these studies, 'Sunny' (1990) and 'Colonial' (1991) fresh-market cultivars were used, and all transplant cultural practices were enumerated. Transplants were pulled and packed in standard wax-lined boxes, shipped to Pennsylvania in mid-May, and stored in a cool barn $(58 \mathrm{~F})$ until hand-planted in the field. In the Florida study, plants were transported to the field in the trays in which they were raised.

In Florida, transplant age did not affect early or total fruit yield. However, the 9-week-old transplants yielded more extra-large fruit than either the 3- or 11-week-old transplants. Transplant age did not affect the average fruit weight of mature-green fruit or cull production (data not shown).

The 1990 Pennsylvania study (single harvest) showed that 4-weekold transplants produced a larger percentage of USDA \#1 fruit than did the 7- or 9-week-old transplants. However, no difference in total marketable yield among treatments was noted. A delay in fruit maturity was observed with the 3- and 4-week-old transplants due to slow field establishment. The 1991 trial showed no differences across transplant ages with respect to yield.

\section{Conclusions}

Based on the studies presented here, several points warrant special consideration. Specialists have tended to encourage growers to use young, actively growing plants, whether this be a 7-week-old plant (Casseres, 1947; Chipman, 1961; Sayre, 1948) or a 4week-old plant (Leskovar et al., 1991a; Nicklow and Minges, 1962; Weston and Zandstra, 1989). Casseres (1947) first noted that "Young plants that were tender and capable of quick growth resumption...were associated with large yields...[and] hardening reduced early yields in proportion to the degree of hardening." Weston (personal communication) argues that physiological inactivity (i.e., older plants) is particularly affected by irrigation and nutrient stresses. The level of stress may result in differing yield responses. Recent studies (Orzolek et al., 1991; Vavrina, 1991) have shown that commercially produced transplants of various ages can produce adequate total yields.

Young plants offer the transplant producer the advantage of reduced production costs (i.e., rapid turnover). However, Hoffman (1929) and Orzolek et al. (1991) found that young plants had to be carried longer in the field to reach optimal yields, which could reduce market window opportunities.

With respect to fruit size, transplants of 3 to 5 weeks of age appear "ideal" for producing large fruit size (Leskovar et al., 1991a; Nicklow and 
Minges, 1962). Others have concluded that the high early yields of young transplants were the result of more fruit, not larger fruit (Orzolek et al., 1991; Weston and Zandstra, 1989). In contrast, Vavrina ( 1991) found that 9-week-old transplants yielded more extra-large fruit in a Florida study.

Earlier yields seem to be produced by older transplants (Hoffman, 1929; Liptay, 1987; Nicklow and Minges, 1962). Early yields are of considerable importance for most fresh market niche growers because of higher market prices. In contrast, Leskovar et al. (1991a) suggest that the traditional 5 to 6-week-old southern containerized transplant offers no early yield advantage compared to a 3- to 5week-old transplant. It should be noted that considerable variation exists in how researchers define early yield (Table 1), so experimental decisions may affect size and volume considerations.

Another consideration in transplant age is cell size, which appears to affect both earliness and yield (Nicklow and Minges, 1962). Liptay (1987) reported that, as cell size diminished, "older" transplants had greater early yields and an improved survival rate under conditions of wind- blown sand. Casseres (1947) attributed higher yields found in widely spaced transplants to reduced root disturbance at field setting. Weston and Zandstra (1986) suggested that "the increased cost of growing in larger cell sizes may be partially overcome by increased early yields."

Other variables also have been implicated in the relationship between transplant age and field production, including: rearing and planting location (Sayre, 1948; Weston and Zandstra, 1986); topping or trimming of transplants (Casseres, 1947; Chipman, 1961; Sayre, 1948); pretransplant nutritional conditioning (Melton and Dufault, 1991; Weston and Zandstra, 1989); and shipping conditions (Leskovar and Cantliffe, 1991b). After more than 60 years of transplant age research, it appears that comparable production can be obtained from tomato transplants of various ages. Apparently, yield differences depend on the innumerable factors involved in commercial production. Those involved in the commercial production of tomato transplants should consider two aspects of transplant age. First,

Table 1. Yields associated with tomato transplant age studies as determined by multiple researchers.

\begin{tabular}{|c|c|c|c|c|c|c|}
\hline \multirow[b]{2}{*}{ Researcher } & \multirow[b]{2}{*}{ Cultivar } & \multirow[b]{2}{*}{$\begin{array}{l}\text { Transplant } \\
\text { age range }\end{array}$} & \multicolumn{3}{|c|}{ Highest yield } & \multirow[b]{2}{*}{ Significant difference $^{2}$} \\
\hline & & & Age & $\begin{array}{c}\text { Early } \\
\text { (lb/plant) }\end{array}$ & $\begin{array}{c}\text { Total } \\
\text { (lb/plant) }\end{array}$ & \\
\hline Hoffman (1927) & --- & $5,6,9,10$ & 5 & & 10.6 & No statistics \\
\hline Casseres (1947) & Earliana & $7,11,15$ & 7 & 0.89 & 11.9 & $7>11,15$ early and total \\
\hline \multirow[t]{3}{*}{ Sayrc $(1948)^{y}$} & John Baer & $6,8,10$ & $\begin{array}{l}6 \\
8\end{array}$ & $\begin{array}{c}3.86 \\
---\end{array}$ & 18.04 & $\begin{array}{l}\text { Average over three locations, } 8>10 \text { carly } \\
\text { NS total }\end{array}$ \\
\hline & John Baer & $10,12,14$ & 10 & 3.49 & $\cdots$ & $\begin{array}{l}\text { Only one location showed difference, } 7> \\
12>14 \text { early }\end{array}$ \\
\hline & & & 10 & & 9.87 & NS total \\
\hline \multirow[t]{4}{*}{ Chipman (1961): } & Scotia & $7-12$ & 7 & 2.6 & --- & $7>$ all $; 9>10,11,12 ;$ all $>12$ early \\
\hline & & & 8 & --- & 8.8 & $8>$ all $; 7>9,10,11,12 ; 11,9>10,12$ total \\
\hline & Scotia & $7-12$ & 7,8 & 15.4 & $-\cdot$ & $\begin{array}{l}7,8>9,10,11,12 ; 9>10,11,12 ; 10> \\
11,12\end{array}$ \\
\hline & & & 7 & $--\cdot$ & 28.5 & $7>$ all; $8>10,12$ total \\
\hline \multirow[t]{4}{*}{ Nicklow \& Minges (1962) } & Fireball & 6,8 & 6 & -- & 11.2 & No statistics \\
\hline & Fireball & $4,6,8$ & 4 & --- & 2.2 & $4>8$ total \\
\hline & Fireball & $3,5,7,9$ & 9 & 0.24 & --- & $9,7>3 \& 5$ early \\
\hline & & & 5 & --- & 12.9 & $3,5>7 \& 9$ total \\
\hline \multirow[t]{2}{*}{ Cooper \& Morelock $(1983)^{x}$} & Traveler '76 & $5,7,9,11$ & 7 & 1.35 & --- & $7,9>5,11$ early \\
\hline & & & 5 & $-\cdots$ & 8.0 & $5>11$ total \\
\hline \multirow[t]{2}{*}{ Liptay (1987) } & $\mathrm{H}-2653$ & $4-7$ & 7 & 4.20 & --- & NS throughout \\
\hline & & & 6 & --- & 7.9 & \\
\hline \multirow[t]{2}{*}{ Weston \& Zandstra (1989) } & Pik-Red & $3-6$ & 4 & 2.23 & --- & $4,5>6,3 ; L^{*} 5>4,6>3$ carly \\
\hline & & & 6 & --- & 17.1 & $6>4,3 ; L^{*} 6>5>4>3$ total \\
\hline \multirow[t]{5}{*}{ Leskovar et al. (1991) } & Sunny & $3-6$ & 5 & 10.20 & -- & Ns-early yield; $Q^{*}=5>4>6>3$ \\
\hline & & & 4 & --- & 25.5 & for early large fruit \\
\hline & & $2-5$ & 4 & 4.11 & --- & NS-total yield; $Q^{*}=4>5>3>6$ \\
\hline & & & 4 & & 15.0 & for total large fruit \\
\hline & Sunny & & & & & NS throughout \\
\hline \multirow[t]{2}{*}{ Vavrina $(1991)$} & Sunny & $3,5,7,9,11$ & 9 & 8.33 & --- & $\begin{array}{l}\text { NS yicld; } Q^{*}=\text { decreasing extra-large fruit } \\
\text { with increasing age }\end{array}$ \\
\hline & & & 9 & --- & 11.9 & \\
\hline \multirow[t]{2}{*}{ Orzolek (1991) } & Sunny & $3,4,7,9,11$ & 4 & --- & 6.9 & $\begin{array}{l}\text { NS yield; } L^{*}=\text { decreasing } \# 1 \text { fruit with } \\
\text { increasing age }\end{array}$ \\
\hline & Colonial & $5,7,9,11,13$ & 13 & --- & 10.1 & NS throughout \\
\hline
\end{tabular}


transplants of 2,3 , and possibly 4 weeks may be difficult to "pull" due to an insufficient root mass to soil volume ratio, and may result in greater field losses. Second, holding plants longer $(7,8$, or 9 weeks) increases the possibility that disease and insect infestations will occur, and reduces greenhouse turnover. These factors often result in increased production costs.

The numerous variables mentioned by the researchers of tomato transplant age indicate that more is at work here than the single issue of age. Nicklow and Minges (1962) suggested, more than 30 years ago, that "tailoring the cultural practices of a new variety may be very important to realizing its maximum potential." While individualizing conditions for each cultivar may be pivotal in solving the dilemma of transplant age, it may seem impractical on a commercial scale due to the number of cultivars planted in a given sequential planting schedule.

Because it is often difficult to schedule transplant deliveries accurately due to field conditions, we believe commercial transplant growers should consider producing a 4- to 7-week-old product for immediate planting on arrival. If significant mortality occurs after transplanting, replanting "older" transplants should not greatly affect tomato culture and yield.

\section{Literature Cited}

Casseres E.H. 1947. Effect of date of sowing, spacing, and foliage trimming of plants in flats on yield of tomatoes. Proc. Amer. Soc. Hort. Sci. 50:285-289.

Chipman. E.W. 1961. The effect of time of seeding and plant topping on the production of early and total yields of ripe tomatoes. Proc. Amer. Soc. Hort. Sci. 77:483486.

Cooper P.E. and T.E. Morelock. 1983. Effect of transplant age on earliness, total yield and fruit weight oftomato. Ark. Farm Res. 32:6.

Hoffman, I.C. 1929. Time of sowing tomato seed for spring crop. Ohio Agr. Expt. Sta. Bul. 431:90-91.

Leskovar. D.I., D.J. Cantliffe, and P.J Stoffella. 199la. Growth and yield of tomato plants in response to age of transplants. J. Amer. Soc. Hort. Sci. 116:416420.

Leskovar D.I. and D.J. Cantliffe. 1991b. Tomato transplant morphology affected by handling and storage. HortScience 26:1377-1379.

Liptay A. 1987. Field survival and estab- lishment of tomato transplants of various age and size. Acta Hort. 220:203-209.

Melton R.M. and R.J. Dufault. 1991. Tomato seedling growth, earliness, yield, and quality following pretransplant nutritional conditioning and low temperature. J. Amer. Soc. Hort. Sci. 116:421-425.

Nicklow. C. and P.A. Minges. 1962. Plant growing factors influencing the field performance of the Fireball tomato variety. Proc. Amer. Soc. Hort. Sci. 81:443-450.

Orzolek M.D., C.S. Vavrina, and R. Scott. 1991. Tomato transplant age study. Penn State 1990-1991 Vegetable Res. Rpt. Hort. Mimeo Ser. II:195. p. 92.

Sayre C.B. 1948. Early and total yields of tomatoes as affected by time of seeding, topping the plants, and space in the flats. Proc. Amer. Soc. Hort. Sci. 51:367-370.

Vavrina, C.S. 1991. Effect of transplant age on tomato production. Proc. Fla. State Hort. Soc. 104:225-226.

Weston, L.A. and B.H. Zandstra. 1986. Effect of root container size and location of production on growth and yield of tomato transplants. J. Amer. Soc. Hort. Sci. 111:498-501.

Weston, L.A. and B.H. Zandstra. 1989. Transplant age and $\mathrm{N}$ and $\mathrm{P}$ nutrition effects on growth and yield of tomatoes. HortScience 24(1):88-90. 